\title{
10. International commercial harmonisation and national resistance - the development and reform of transnational commercial law and its application within national legal culture
}

\section{Maren Heidemann*}

\section{INTRODUCTION}

\subsection{General Theory of Harmonisation}

A theory of harmonisation has to be based on sound analysis of the underlying concepts in both law and its language. While one difficulty in developing a coherent theory of harmonisation of laws is the fact that the term is used in the context of a specific area of EU legislative activity, an excellent starting point is the word harmony itself. The word appears in only slightly different versions in many languages across the world. The meaning depends on the context, but certainly includes a pleasant accord of circumstances. Going beyond this rather vague and seemingly random meaning of harmony one has to realise that harmony was an important element in all the classic Greek scientific disciplines, and therefore plays a part not only in the seemingly vague concept of musical harmony (which springs to mind first) but also in mathematics, physics, astronomy, philosophy and certainly medicine. The reason is that harmony describes a precise system of proportionality, of proportions as they occur in nature. Harmony is part of the laws of nature. An harmonious chord is built on an exact ratio between individual tones, ie, their amplitudes, for instance, the octave, the third and the fifth. This is a natural phenomenon which has been used in architecture and all arts throughout history. Harmony depicts the natural

* University of London, UK. 
proportions of nature, such as the human body and even the universe. We can therefore say that harmony is a very precise concept, not at all vague or random, and can therefore also serve as a scientific term in the legal science. Developing a meaningful theory of harmonisation of laws could among other things entail an attempt to analyse which figures and numbers can be observed within the process in order to work out whether it might be possible to achieve an ideal proportion. On a more general level, it is my submission that a theory of harmonisation must include a two-way activity. The one-way legislative process currently carried out by the EU can lead to resistance within the national legal systems and would therefore amount to a uniformisation process. Harmonisation would require a complementary action emanating from the national legal systems with a view to achieving harmony on a transnational level. Examples have been presented throughout the workshop in the context of, e.g., international criminal law, the European Human Rights Convention and its margin of appreciation, and even in the area of EU regulations which unwittingly fail to achieve their goal of uniformity and depend on this active harmonising contribution on the part of the national legal systems.

This complementary role of national law in the harmonisation process is the subject of my contribution.

\subsection{Harmonisation as a Two-way System}

International contract and commercial law has recently been subject to reform through a process of co-operation in civil and commercial matters within the EU.

A number of EU directives and regulations in the area of private and commercial law have been adopted or are being drafted and in the process of formal adoption. The complementary element to this growing effort of harmonisation and uniformisation in order to advance the internal market cross-border trade is, of course, the application of substantive legal norms forming part of international and transnational law. Without a culture of applying international and transnational legal rules, the process of harmonisation remains a 'top-down' process which may not achieve its ultimate objectives.

In the area of private and commercial law, three elements of applying law to cross-border situations can be identified and illustrated here:

- the skill of applying substantive norms of transnational contract law;

- the willingness to acknowledge foreign legal concepts and draft legislation with a view to developing international instruments; and

- the appropriate consideration of foreign legal positions or even precedence in domestic proceedings in international matters. 


\section{THE APPLICATION OF TRANSNATIONAL CONTRACT LAW: SKILFUL LEGISLATION AND APPLICATION IS A PREREQUISITE TO UNFOLD ITS POTENTIAL}

The application of transnational contract law requires two stages - the stage of the conflict of laws and that of the application of individual rules.

\subsection{Transnational Law in the Conflict of Laws: Legislators and the Courts}

The conflict of laws position distinguishes between the areas of state court litigation and of arbitration. Legal doctrine has developed a mode of language whereby 'law' stands for the law of a state and 'rule of law' includes so-called 'soft law' which comprises instruments such as Model Laws, UNIDROIT principles, PECL or CISG.

The reform of the conflict of laws through the proposed 'Rome I' Regulation originally intended to allow in its Article 3(1) for certain non-state laws to govern international contracts (by way of express choice of law) by introducing a previously unused formula: 'recognised internationally or in the Community'.

The idea of allowing 'soft law' to govern international contracts had already been manifested in the UNCITRAL Model Law on International Arbitration. The reformed German code of civil procedure, ${ }^{2}$ however, does not reflect the effort of incorporating this Model into the German law of arbitration. ${ }^{3}$

In the UK, the Arbitration Act 1996 does leave room for the open choice corresponding to the Model. The generally sceptical attitude of the courts towards a choice of non-state law does not generally preclude this possibility. ${ }^{4}$

However, a quantitative study ${ }^{5}$ shows a marginal use of non-state law in international arbitration. (Between 1 and $2 \%$ of reported ICC arbitration cases between 2000 and 2006 show the use of transnational law as the law governing the contract). So, is the current legal framework the reason for the low numbers of awards based on non-national law? Is the low number of published arbitration awards based on non-state law a reason to abandon further research into this matter or is it an indicator of a need to support this type of legal regime?

\footnotetext{
1 Draft Council Regulation, COM(2005)650 final. See below, 3.1.2, for further discussion.

2 Code of Civil Procedure, Zivilprozessordnung, the ZPO, in $\$ \$ 1025-1066$ (10th book), revised 22 December 1997 and in force since 1 January 1998.

3 See below, 3.1.1, for further discussion.

4 See below, 3.1.2, for further discussion.

5 Dasser, Felix (2008, forthcoming), 'Mouse or Monster? Some Facts and Figures on the Lex Mercatoria', 4 in R Zimmerman et al. (eds) Globalisierung und Entstaatlichung des Rechts (Mohr Siebeck, 2008), 129 et seq.
} 
It seems that choice of law clauses to the exclusion of national contract law are a regular occurrence ${ }^{6}$ and hence a need in commercial contracts. Given the high financial value of international commercial arbitration this ought to be of concern to legislators. Transnational contract law is the response to the need for a specialised law for international commercial contracts, a form of lex specialis.

The concept of transnational contract law is still treated with great caution within national legal systems, and as a result is accompanied by a considerable degree of legal uncertainty. Transnational law is therefore a good example to illustrate differing standards of legislative skill in recent law reform projects in English and German arbitration and conflict law.

The purpose now is not primarily to look at the effect of the legal rules mentioned above but rather the process of their making. ${ }^{7}$

\subsubsection{Reform of the German arbitration law}

Recent reform projects concerned arbitration law, both in Germany and in England. The new $\$ 1051$ ZPO had been expressly drafted with a view to incorporating the UNCITRAL Model Law and with reference to other European arbitration laws. The objective was to make Germany a more attractive place for arbitration and, to this end, to approximate the German arbitration law to international standards. This can be seen from the Official Reasons published by the government. ${ }^{8}$

Now, looking at the text of the UNCITRAL Model Law, it can be seen that a choice of non-national law was intended to be permissible by the drafters of this text. This can be deduced from the wording 'rules of law' which by convention hints at the application of state law and soft law, while the wording 'law' would indicate that only state law is encompassed by the term. The German ZPO incorporated this aspect in its paragraph 1 ('according to the rules of law') on express choice of law. However, in the second paragraph, the legislator has stipulated that, in the absence of choice, 'the tribunal applies the law of the state with which the matter is most closely connected'. This differs from the provision in paragraph 2 of Article 28 of the Model Law which gives the arbitration tribunal a discretion to decide which 'conflict of laws rules it considers applicable'. This wording gives the arbitrator a maximum of flexibility in order to deal with

6 A good example from state court litigation is Eurotunnel v. Balfour Beatty [1992] 2 Lloyd's Rep 7 (CA); [1993] 1 Lloyd's Rep 291 (HL), and an illustrative example in arbitration is ICC No 7110, cf Ly, F d (1999) 'Dutch National Report' in Bonell, MJ (ed) A New Approach to International Commercial Contracts (Kluwer Law International) at 203-35.

7 Contrary to the advice of our elder statesmen never to investigate the making of sausages or the making of laws.

8 Bundestags-Drucksache (BT-Drucks) 13/5274. 
the individual case on behalf of the parties without overstepping the marks still guarded by traditional legal science.

The German legislator, however, has created a different and, looking at both form and substance, rather peculiar rule. Not only is there no mention of a discretion for the arbitrator and the allusion to non-state law but, on the contrary, the section prescribes a very strict rule: 'the tribunal applies the law of the state with which the matter is most closely connected'. This makes a clear choice in favour of state law exclusively, and at the same time prescribes the criterion to be applied in order to arrive at the proper law of the contract, which the UNCITRAL Model Law does not. Formally, this rules poses a riddle: the legislator has set this brief rule up but has not clarified how it relates to the general rules of the German conflict law which is incorporated in the so-called 'Introductory Code to the Civil Code', the EGBGB. ${ }^{9}$ In this codification, the legislator implemented the Rome Convention in 1986, and its Article 28 is nearly identical to the Convention. This means that Article 28 EGBGB gives a list of guidelines relating to specific contract types and in its paragraph 5 offers an exception to these in order to give effect to unusual situations: ' $\mathrm{t}$ ] he presumptions of paras 2, 3 and 4 are not to be applied if on the whole the contract has a closer connection with a different state'. Now, it seems that the German legislator of the new ZPO assumed that these guidelines and the whole Article 28 EGBGB would automatically apply to $\S 1051 \mathrm{ZPO}$ and therefore the rules did not need repeating. This is not the case, however. Methodically, it is clear that the ZPO is a lex specialis and will supersede the general rules of the EGBGB, not to mention the difference in wording between the two rules which suggests that $§ 1051$ (2) ZPO is not identical in substance with Article 28 EGBGB. ${ }^{10}$ The questions which this poses have not been answered by the legislator. On the contrary, the Official Reasons state that it was assumed that Article 28 EGBGB would automatically apply; they also state that this provision was identical with the arbitration laws of many other European jurisdictions, for example, the Swiss. Both suggestions are incorrect. ${ }^{11}$ In addition, it has to be mentioned that should the arbitrator ignore $\S 1051 \mathrm{ZPO}$ and, for instance, decide according to the Model Law and arrive at a law or set of rules which is not in accordance with $\S 1051 \mathrm{ZPO}$, this decision

9 Einführungsgestz zum Bürgerlichen Gesetzbuch (EGBGB), 'Introductory Law to the BGB', first enacted on 18 August 1896.

10 Cf in more detail Solomon, D (1997), 'Das vom Schiedsgericht in der Sache anzuwendende Recht nach dem Entwurf eines Gesetzes zur Neuregelung des Schiedsverfahrensrechts', 12 Recht der InternationalenWirtschaft 981-90 and Heidemann, M (2007), Methodology of Uniform Law: the UNIDROIT Principles in International Legal Doctrine and Practice (Springer) Chapter 8.

11 For reasons of space, this question cannot be analysed any further here, but compare, ibid. 
would not be overturned by a German court. Unlike English law, German law does not review arbitration awards on the merits (regarding the application of German law) but would overturn the award only if the arbitrator has exceeded his powers, for example, if he had decided ex aequo et bono without being authorised to do so. As long as the arbitrator announces that he or she is applying law or rules of law, however, this will not be assumed to be the case. ${ }^{12}$

Conclusion 1: The German legislator has enacted a rule which is not only meaningless but obviously very insufficiently thought through. It has to be assumed that it was unknown or irrelevant to the drafters how this new rule would fit in with this area of law. This is unfavourable for the development of international commercial law and does not help the express aim of the legislator of making the German law of arbitration both more attractive and more consistent with international models.

\subsubsection{Transnational law in the courts}

Despite the critical attitude of both the German and the English legislatures, the courts, both in England and Germany have never overturned an arbitration award based on anational law so far. This is particularly interesting in the case of English courts as the Arbitration Act 1996 upholds the traditional powers to review awards on grounds of wrongly applying English law and the attitude of English judges is traditionally very critical towards arbitration and the application of non-state rules. ${ }^{13}$ Two cases in more recent times have come very close to the question of the legitimacy of non-state law or whether 'soft law' could be the proper law of the contract: Eurotunnel v. Balfour Beatty [1992] 2 Lloyd's Rep 7 (CA); [1993] 1 Lloyd's Rep 291 (HL) and Halpern \& Ors v. Halpern \& Anr [2007] EWCA Civ 291. In the first case, the House of Lords confirmed that an arbitration clause was to be respected, and did not, as might have been hoped for by the parties, consider that the choice of 'principles common to both English and French law' was an inadmissible choice of law. The case did not, however, require this question to be decided, and a warning remark was included in the judgment questioning the advisability of such choices. In the case of Halpern, an inheritance dispute among members of an orthodox Jewish family, the defendants sought Jewish law to be the proper law of the contract. ${ }^{14}$ This submission was by no means bluntly rejected by the judge (Waller LJ). The

12 BGH NJW (1986) 1437, which also expressly states that the wrong application of the correct law is not subject to judicial review. See also Heidemann, supra n. 10, at 210.

13 Cf Charnikow v. Roth Schmidt \& Co [1922] 2 KB 478.

14 As this would have allowed a more favourable law of restitution: see case note by Heidemann, M (2008), 'Halpern v Halpern: Zur Anwendbarkeit nicht-staatlichen Rechts und "Rom I" in England - Entscheidung des englischen Court of Appeal vom 3 April 2007', 3 ZEuP, 618. 
court considered that there might be circumstances in which such law could be the proper law of the contract, but that it was not to be regarded as an express choice of law under the Rome Convention and consequently under the Contracts (Applicable Law) Act 1990. This is a remarkable way of putting it, as it does not expressly exclude the possibility of choosing anational law but states that in this case, under English law, it did not amount to an express choice and was not applicable otherwise. The new draft Rome I Regulation on choice of law within the European Community was discussed in the course of the proceedings. The first draft of this Regulation suggested the applicability of certain 'soft law' which the defendant's/respondent's counsel mentioned. Again, this argument did not make a difference to the position under English law, and with the new draft all these considerations will be irrelevant, anyway.

Conclusion 2: Despite the indifferent or outright negative attitude of legislators towards non-state contract law, courts have maintained a more open-minded attitude with a view to allowing the evolution of international commercial and private international contract law as far as a wider use of non-state law would be desired. The use of uniform, tailor-made rules of law can aid and benefit international trade and other private cross-border activities. This development has been jeopardised by the enactment of the Regulation (EC) No. 593/2008, (Rome I).

\subsection{Reform of the German Civil Code}

A second example from recent German law reform is to be found in the new BGB which was reformed with effect from 2002. Again, the legislator has published the intention to align German law with international instruments (in the Official Reasons). ${ }^{15}$ In order to disentangle the highly complicated structure of the German law of impossibility, non-performance and frustration in contractual relations, a new notion was devised - the so-called breach of duty. I have deliberately translated this expression as literally as possible from the German word Pflichtverletzung in order to illustrate all its implications within the context of international instruments of contract law. For instance, the Official Reasons refer to the 1980 Vienna Sales Convention, the CISG, pointing out that German law has incorporated the notion used in this Convention: non-performance. The text states that the difference in wording is only clerical or editorial, a mere verbal difference but with no legal meaning. One does not have to be a specialist in private international law to detect a problem with such an attitude to legal texts. Non-performance and breach of duty are very much two different legal concepts. As with many international instruments, the CISG was drafted in the

15 Official Reasons, BGB, Parliamentary Bulletin No 14/6040, 14 May 2001, at 1992. 
form of a blend or a compromise between various legal traditions and concepts so as to find the best solution, and one which would be acceptable to as many jurisdictions as possible. The concept of non-performance is not equal to the common law concept of breach of contract, but is based on this, in so far as it pursues a more holistic understanding of the contract. It is an attempt to simplify contractual performance and reach clear-cut solutions in cases where performance does not go to plan. The so-called civil law or continental systems which work with the law of obligations have a different understanding of contract. A contract is a network of obligations which are reciprocal, and all of these need to be discharged in order for the contract to be fulfilled or the obligations otherwise lifted. This structure was taken to the extreme in the German BGB and in particular the old $\S 323$ and the whole network of provisions relating to cases of impossibility and non-performance. Non-performance was not a starting point as such, but rather what was called a disturbed performance. This expression sought to describe the act of discharging the various elements of the contract in a value-neutral way. Contract law, civil law in general, has never been about value judgements or moral attitude, but rather first and foremost about balancing economic interests. The new expression, 'breach of duty', reminds one too much of a moralising attitude towards dutifulness and does not fit the picture from this angle alone. Furthermore, it is a new concept and expression which is not in line at all with either common law systems or international instruments which incorporate a completely different concept of contract. This is not what the German legislator had in mind though. The general system of individually connected obligations has been maintained, rather than replaced with a more simplistic concept of non-performance. It is not the breach of a duty but the non-performance which is the basis of contractual failure in international instruments. If the German legislator had wanted to align the contract law to international instruments, this would have been the best choice. The now existing solution represents a completely novel concept, which needs explaining to both German and international lawyers.

Conclusion 3: The German legislator has failed to align the German contract law with international instruments despite express intentions to do so. Subtleties of different legal concepts seem to be unnoticed by the drafters, which suggest a lack of interest or skills. This is unfavourable for the development of a culture of transnational law.

\subsection{Application of Individual Norms of Transnational Contract Law}

In order to complete the picture, some thoughts should be sketched here regarding the application of rules of uniform commercial law such as CISG, the PECL or the UNIDROIT Principles of Commercial Contracts. By way of example it is interesting to look at an instance where Article 7.2.1 of the UNIDROIT 
Principles has been analysed by a scholar ${ }^{16}$ in a way which shows how problems arise which could be easily avoided. Professor Schwenzer considered the payment rule in Article 7.2.1 UPICC an overly rigid rule which would not be compatible with any European jurisdiction, as none of them grants an unqualified right to performance. She arrived at this conclusion by comparing Article 7.2.1 with Article 7.2.2, which contains a list of exceptions to the general rule of requiring performance (of non-monetary obligations). She did not, however, take a closer look at the UPICC and she did not apply them as a whole in the way of a contract code. Therefore, she did not consider all the limitations and exceptions which the Principles contain as general rules (just as any domestic law does) and which by no means create an overly rigid right to performance which would clash with domestic legal systems. The UPICC are one of several international instruments which allow a comprehensive application of all their rules in the way of a contract code. If this were done in the same way as lawyers apply their own domestic law, comprehensively, they would see fewer 'gaps' in the uniform international law to start with. ${ }^{17}$

A similarly fragmentary method of application can be observed in some case law, often in the context of trying to establish general principles of law. ${ }^{18}$ The good faith rule of the UPICC is often quoted as proof of this principle in international law, but often in an isolated manner as if the UPICC were a collection of random rules when they are really a unique set of rules that is extraordinarily suited to be used in the style of a code. The isolated way of using these rules can lead to misconceptions and subsequently to a general sense of unsuitability of such law to solve complex cases.

More conceptual resentments such as the general rejection of the concept of specific performance upon a brief inspection of Article 7.2.1 UPICC are equally based on a very superficial look at one's own legal system. A careful comparison of the extent to which both the German (as a civil law system) and the English (as a common law jurisdiction) legal systems grant payment rights demonstrates that the UPICC, if applied properly, will in substance be compatible with those systems and how an application can be facilitated. ${ }^{19}$

The willingness to apply such uniform law is an indispensable prerequisite for a successful integration into the legal process. And this includes the aspect of conflict of laws which functions as a gateway for uniform commercial law

16 Schwenzer, I (1998/1999), 'Specific Performance and Damages According to the 1994 UNIDROIT Principles of International Commercial Contracts', 1 European Journal of Law Reform 289.

17 See for in-depth discussion of this method Heidemann, supra n. 10, Chapters 4 and 5 .

18 Available at www.unilex.info.

19 See Heidemann, supra n. 10. 
into the sphere of domestic law. Legal doctrine has to provide solutions for this if this law is to play a role in cross-border trade. Questions of legitimacy have to be addressed in view of the fact that national law will necessarily always address domestic contracts as the national legislator's competence ends at the borders of a territory while international contracts can span the whole globe. So, rules of international trade law have a quality of lex specialis as they deal with international contracts. ${ }^{20}$

Conclusion 4: In conclusion, it can be said that many of the current problems in international trade law are based on misconceived aspects of private law which can be avoided by referring to the jurisprudential foundations of each jurisdiction's own tradition. Theories of contract law and the general doctrine of construction can help overcome prejudices and seemingly insurmountable obstacles in the application of modern trade law.

\section{3 'RESISTANCE' BY WAY OF EXTRA-LEGAL ARGUMENTS: THE HORROR ALIENI}

\subsection{International Company Law: Adverse Practices}

On a more anecdotal level, it must be observed that, even after the decisions of the ECJ on freedom of establishment and free movement of companies, migrating companies are still not exactly welcome in the host European state. The German business community still maintains a campaign-style adversity against specifically English limited companies. Following a wave of formation of 'Ltds' predating the Überseering ${ }^{21}$ decision by the ECJ, by what is thought to be $46,000^{22}$ German small businesses, both private actors ${ }^{23}$ and state authorities ${ }^{24}$ started to denigrate this form of incorporation. Banks are known to refuse to open accounts for 'Ltds', business partners are reluctant to enter into contracts and the tax offices are advised that most Ltds are 'letter box' companies (because the practice of having the registered office and the head office in different places is not familiar to them). These assumptions were of course originally based on the doctrine of the real seat ${ }^{25}$ which was

\footnotetext{
20 See below at 3.2 .

21 Case C-208/00.

22 This is said to be the unofficial count, dramatically called Dunkelziffer, while about 7,000 English private limited companies are registered in the German Handelsregister.

23 Banks refusing to open accounts for 'Ltds'.

24 The Federal Tax Office regularly found that 'Ltds' were not to be recognised in terms of a permanent establishment in Germany.

25 Sitztheorie.
} 
subsequently dismissed by the ECJ in favour of the doctrine of incorporation. The mindset did not change, though, with the case law. Critics wait for a sign in the ECJ decisions allowing the reintroduction of the seat theory. They find hints in the concession that 'abuse' should certainly not be supported in Cadbury Schweppes. ${ }^{26}$

The arguments on which the rejection of foreign companies, and in particular the British limited company, is based are the difference in minimum share capital which is said to pose an enormous risk to creditors, ${ }^{27}$ a lack of personal liability of the directors and a dubious degree of truthfulness of the register at Companies House. ${ }^{28}$ These arguments are, of course, wholly unfounded. ${ }^{29}$ However, the extent of this attitude clearly shows that irrational behaviour reigns, rather than the principle of mutual recognition and non-discrimination, and the wrong subject is targeted by these campaigns: as much as it might be unfavourable for sole traders such as hairdressers or plumbers to set up an English Private Limited Company because they incur double filing obligations in both countries in terms of annual reports and tax returns, it is not the Limited Company as such which poses the problem, and ignorance is no excuse for the unhelpful behaviour towards foreign companies.

\subsection{Cartesio: AG Maduro's Opinion}

This problem stems from and illustrates once again the complex relationship between private law and the state. Looking at the latest case brought before the ECJ regarding international company law, Cartesio,${ }^{30}$ this comes to the fore once again. Advocate General Maduro gives an interesting description of the issues involved in his Opinion. ${ }^{31} \mathrm{He}$ states, in paragraph 31 :

26 Centros Ltd v. Erhverus- og Selskabsstyrelsen, Case C-196/04.

27 In Denmark this problem was apparently solved by effectively transferring the requirement of a minimum share capital into tax law to prevent Centros from registering in Denmark (cf Case C-21/97).

28 The practice of acquiring 'off-the-shelf companies', as well as the practice of having a separate registered and head office, leads to the assumption that every British company is a 'letterbox company' and cannot be trusted. The register at Companies House is feared not to provide up-to-date information about the authorised representatives of companies.

29 Not many creditors really turn to the share capital in order to satisfy outstanding debts, but rather to the established and well known procedures of debt collection through different types of security. The German company registers can certainly contain incorrect information in certain instances, as can the records at Companies House. Of course, there is a director's liability in certain cases under English law.

30 Cartesio Oktató és Szolgáltató bt. Case C-210/06.

31 Opinion of Advocate General Poiares Maduro delivered on 22 May 2008 (1) in Case C-210/06, Cartesio Oktató és Szolgáltató bt. 
In sum, it is impossible, in my view, to argue on the basis of the current state of Community law that Member States enjoy an absolute freedom to determine the 'life and death' of companies constituted under their domestic law, irrespective of the consequences for the freedom of establishment. Otherwise, Member States would have carte blanche to impose a 'death sentence' on a company constituted under its laws just because it had decided to exercise the freedom of establishment.

The question really is: what does the state have to do with the establishment of a company which is ultimately a contract between several private individuals to carry on a commercial activity? The company registers are not necessarily a state organ or run by a state organ and do not as such confer legal status on the companies, and so while the company owes its status as a legal person to the law in the state where it is established, does this mean it vanishes when it 'leaves' that state? This touches on the quality of law as such, in particular in private law. The current prevailing doctrine of the unity of law and state will find it hard to give answers which further the development of the Community trade which we currently see evolving. The solution, in my view, has to come from the recognition of a legal pluralism, for instance in the way which Gunther Teubner has suggested by 'reframing' legal sources, ${ }^{32}$ and of course by genuinely recognising party autonomy.

Another important argument in this context is mentioned in paragraph 32 of AG Maduro's Opinion:

Consequently, even though the restriction on the right to freedom of establishment at issue in the present case arises directly from national rules on the incorporation and functioning of companies, the question has to be asked whether they can be justified on grounds of general public interest, such as the prevention of abuse or fraudulent conduct, or the protection of the interests of, for instance, creditors, minority shareholders, employees or the tax authorities.

The argument of abuse is, as I mentioned briefly above, eagerly welcomed by those who prefer to classify companies purely under the doctrine of the real (de facto) seat, the place of the operational headquarters, and disagree with the free movement of companies throughout the EU. This argument, however, is in my view totally out of place in the context of the EU. The act of forming a company in any of the European Member States must pre-empt any reproach of abusive behaviour. Moving freely across borders needs to be fully recognised and practised by both individuals and state authorities as it is an important objective of the EU.

Last but not least, it appears questionable whether the tax authorities can claim an independent right to have taxation opportunities arising from their

\footnotetext{
32 Teubner, G (2002), 'Breaking Frames: Economic Globalisation and the Emergence of the Lex Mercatoria', 5 European Journal of Social Theory 199.
} 


\section{FOR EDUCATIONAL USE ONLY}

Theory and practice of harmonisation

national laws or even the movement of the companies, protected, as confirmed in Daily Mail. ${ }^{33}$ After all, even if Cartesio will be allowed to move to Italy without dissolving and re-establishing themselves under Hungarian and Italian company law, the Daily Mail principle still holds, and it is clear that at least the German hairdressers and plumbers will find it difficult to tax their business assets (stille Reserven) in the country of origin and start again in the new country.

\subsection{Professional Envy}

In a similar way of veiling alleged economic advantages, the preoccupation with transnational law is deemed to be a purposeful development of young scholars who want to create their own niche subject. Repeatedly, arguments against choices pointing away from Germany include the economic advantage and success of the City of London as a place of arbitration and the seat of wealthy law firms as an ulterior motive of canny lawyers to sway the judgment of naive recipients of advice. ${ }^{34}$ This just underlines that there is and should be a competition between the different European jurisdictions, and that the citizens are making choices in order to find the best solutions for themselves.

\section{THE ROLE OF THE LEGAL UNDERSTANDING OF THE OTHER SIDE: INTERNATIONAL PRECEDENCE, INTERPRETATION OF TREATIES AND COMITY}

The previous discussion has shown that taxation law is an integral part of the free movement of companies and individuals within Europe and it is intrinsically linked to freedom of establishment. As there is only a rudimentary and fragmentary body of EC taxation law most of these issues are still subject to national laws and bilateral treaties between the Member States. It is therefore interesting to look at the standards that apply to promoting cross-border activity in this area.

33 Case $81 / 87$. This might even be the strongest driving force behind the reluctance to embrace the free movement of companies which the Danish example illustrates.

34 Cf Mankowski, P (2003), 'Rechtswahl für Verträge des internationalen Wirtschaftsverkehrs' 1 Recht der International Wirtschaft ( RIW) 2 and Heidemann, supra n. 10, Chapter 8. In this article, Mankowski recommends the use of CISG for international commercial contracts - however he discourages the use of UNIDROIT Principles even though the very same arguments which he uses obviously speak in favour the UPICC, too. CISG needs this support from scholarly writing in Germany as routinely excluding it from applying to international contracts still is standard practice in the legal profession. 
What I am looking for here is the extent to which the attitude within the national legal system supports or acknowledges the fact that cross-border activity is increasing within the EU and also worldwide.

Comparing practices in the UK and Germany, it can be seen that there are differing ways of including foreign legal positions, and in particular judgments, in legal reasoning. While it is fairly common in English judgments to consider case law from other jurisdictions, this is not common in Germany. With regard to Double Taxation Treaties (DTTs), this has been analysed by Moessner, Lang and Waldburger, three tax experts (law professors and senior judges) from Germany, Austria and Switzerland who have analysed the considerations of foreign decisions in German judgments of the Federal Taxation Court, the Bundesfinanzhof, BFH, between 1957 and 1994. Professor Moessner found 27 instances of consulting foreign case law in those 37 years. While this is not a high number, it is also striking that those instances mostly concerned the DTTs entered into by Germany with the USA and Switzerland. Due to the fact that a large proportion of the German case law on double taxation has emanated from litigation concerning those two treaties, it is all the more interesting to look at the position regarding the DTT between Germany and the UK.

\subsection{Different Views on the Application of a Bilateral Treaty: the Silent Partnership}

A peculiar example to observe in German-UK taxation law is the taxation of the silent partnership. We can observe two interestingly diverging legal standpoints as well as, after all, a positive move within German case law towards recognising the view of the other party (if yet again arising from a case about the German-US DTT). ${ }^{35}$ The German courts have ignored the British viewpoint on the matter entirely, in contravention of international law, but there is now a move towards recognising the view of the partner of the bilateral treaty.

Between the UK and Germany there are considerable discrepancies as to the understanding of silent partnerships. Some legal systems, such as the German, subdivide silent partnerships into plain ones and so-called atypical silent partnerships. English law does not recognise this distinction. Not surprisingly, the distinction is not expressly mentioned in the DTT. (Only four DTTs concluded by Germany with other states include this distinction, those with Luxembourg, the Netherlands, Austria and Tunisia.) The current German practice classifies income and proceeds from sales of atypical silent partnerships as business profits, attributed to the permanent establishment of this entity (Article 3

35 See below. 
DTT), while the UK sees these earnings merely as dividends ${ }^{36}$ or - in the case of the sale of the main share - simple debt collection (Article 6(4) DTT). This discrepancy arises not only from a generally diverging company law, but predominantly due to a flawed technique of applying rules of international law by the German authorities and courts. The DTT contains substantive rules creating sources of income sui generis and includes provisions about the distribution of income between the contracting states, as well as about avoidance of double taxation and double non-taxation (tax avoidance). The fact that the atypical silent partnership is not mentioned in the DTT does not justify the application of Article II (3) DTT ${ }^{37}$ in a way which amounts to using the rule in the sense of a conflict rule, pointing to the full application of German law. ${ }^{38}$ This method is contrary to Article 31 (1) of the Vienna Convention on the Law of Treaties, which states that the wording of a rule is the limit of possible interpretation. The correct development of a treaty-specific autonomous meaning of the relevant terms of the DTT (enterprise, business profits, silent partnership) can be found, however, in the English cases of Memec plc, ${ }^{39}$ where the courts set out the criteria by which the meaning is to be established and point out that understanding of the terminology in DTTs has to be specific to each Article and cannot simply be taken from another DTT Article or from English law. The starting point for the analysis is the understanding of the ordinary businessman. Notably, the judges also take German case law (again, on the Swiss DTT) into account when determining the nature of the German silent partnership. No mention is made of an atypical form of silent partnership, even though Memec plc was in fact an atypical silent partner of its German subsidiary. Instead, the nature of the business venture of the (atypical) silent partner Memec plc was correctly described as:

The position of Plc was that of a purchaser who, for a consideration consisting of the contribution of a capital sum and an undertaking to contribute to losses of the owner

\footnotetext{
36 Memec plc v. Inland Revenue Commissioners (IRC) [1996] STC 1336 (Ch D); [1998] STC 754 (CA).

37 The interpretation rule of Art. 2(3) DTT, the so-called Oeffnungsklausel.

38 German law classes the profits of the atypical silent partner as business profits according to $\$ 15 \mathrm{EStG}$, the domestic income tax law going merely by the fact that the silent partner has agreed to take part in the losses of the principal as well as hold certain information rights in respect of the principal's business which itself can be a share in another business. There are inconsistencies between this legal situation and other taxation laws such as the definition of business in the law of corporation tax and value added tax. There are also clashes with the company law aspect of this scenario. Thus the whole viewpoint of the German tax authorities and courts on this matter appears highly remote, even within domestic law.

39 See previous note.
} 
of a business up to the amount of the contribution, purchased a right to income of a fluctuating amount calculated as a share of the annual profits of the business. Neither in English nor in Scottish law would that have left Plc a partner with $\mathrm{GmbH} .{ }^{40}$

The English court arrived at the conclusion that such an activity cannot generate business profits under the German-British DTT - exactly the opposite stance to that which the German courts have been taking in cases which notably did not involve the German-British DTT but mainly Swiss cases. ${ }^{41}$ The last relevant decision was made by the BFH in $1999^{42}$ (regarding a German-Swiss case) and this ended a previously lively academic discussion about the correct way of classifying the atypical silent partnership according to an autonomous interpretation of the DTT. ${ }^{43}$ On the part of the tax authorities, the underlying argument seems to be that insofar as there is no double taxation resulting from the different views on the qualification of the sources of income, there is no need for a coherent application of the DTT. ${ }^{44}$ This is an insufficient argument under international law. The Memec decisions and the 1999 BFH decisions were followed by the OECD Report on the taxation of partnerships ${ }^{45}$ which seemed to induce this line of argument. It does, however, presume that a sufficient interpretation and application of DTTs has been carried out before gaps or unregulated matters can be assumed. This is not the case in the silent partnership cases.

Newer German case law shows a shift towards an awareness of the significance of the legal position in the partner country. The BFH's judgment of 17 October 2007, IR 5/06 concerned the taxation of interest which a US-based shareholder earned under the German-USA DTT. The BFH made it very clear that the mere non-intervention of the US authorities with regard to a practice of the German authorities which contravened the DTT does not amount to an

40 Henry LJ in Memec plc v. Inland Revenue Commissioners (IRC)CA [1998] STC 754,756 . Memec plc was consequently denied the set-off of German local business tax (Gewerbesteuer) paid on the profits.

41 It should be noted that the outcome of these cases by no means always favours the German fiscus. This can therefore not be the motivation for the legal views of the courts on this point of law.

42 BFH (German Supreme Tax Court) Urteil vom (judgment of) 21 July 1999, BStBL II 1999, 812 = FR 1999, 1361.

43 A comprehensive overview of this discussion is given by Geuenich, M (2005), Qualifikationskonflikte im OECD-Musterabkommen und deutschen Doppelbesteuerungsabkommen am Beispiel der atypisch stillen Gesellschaft (Schriften zum Steuerrecht, Duncker \& Humblot, 2005) at 46-7.

44 Cf BMF (Bundesministerium für Finanzen) 'letter' of 28 December 1999, IV D 3-S 1300-25/99, in Internationales Steuerrecht (IStR) 2000, at 24.

45 OECD, The Application of the OECD Model Tax Convention to Partnerships (OECD Publications, 1999). 


\section{FOR EDUCATIONAL USE ONLY}

196

Theory and practice of harmonisation

'understanding' ${ }^{46}$ between the contracting parties, and hence to an agreement about this practice. Here, for the first time, the BFH looks at the viewpoint of the partner state..$^{47}$ The court applies the Vienna Convention on the Law of Treaties extensively. The BFH also expressly distinguishes between legal solutions applicable under the German-US Treaty and potentially different solutions under the German-Swiss DTT, ie, the court recognises that the DTTs have to be individually interpreted in the light of the intentions and mutual understanding of the contracting parties. ${ }^{48}$

This has a lot of potential for the future development in this area of law and means that the German authorities and courts may have to recognise the English view expressed in Memec plc.

\subsection{International Precedent?}

The previous considerations have aimed at demonstrating instances of recognising foreign law within the formation of domestic legal opinions and case law.

Taking this idea further, there are considerations within the framework of civil and commercial co-operation as to whether judgments of supreme national courts can affect the interpretation of Community law, for instance in insolvency proceedings. While this could be resolved by way of a preliminary ruling as it is part of the acquis, recourse needs to be had to general principles in the case of bilateral treaties.

These general principles are discussed within German-speaking doctrine in the context of Entscheidungsharmonie, harmonising decision-making (also discussed within the context of DTTs) and Vertrauensprinzip, the principle of mutual trust in international public law. ${ }^{49}$

Three Austrian cases of the supreme court (Oberster Gerichsthof) ${ }^{50}$ apply Article 15 of the Insolvency Regulation (1346/2000) differently from the way the High Court did in the case of Mazur Media (HC 03 C4269, July 2004, paragraph 70). There is a discrepancy between the way the relationship between Article 4 and Article 15 of Regulation 1346/2000 51 is seen and the way the

\footnotetext{
46 According to Art. 31 (3) of the Vienna Convention on the Law of Treaties (1969) (signed 23 May 1969, entered into force on 27 January 1980).

47 BFH 17 October 2007 - I R 5/06, II b) dd) bbb).

48 Ibid., at II b) ee).

49 Mössner, JM, Waldburger, R and Lang, M, Die Auslegung von DoppelbesteuerungsabKommen in der Rechtsprechung der Höchstgerichte Deutschlands, der Schweg und Österreiche (Linde Verlag, 1998) at 57 et seq.

$508 \mathrm{Ob} 131 / 04 \mathrm{~d} ; 9 \mathrm{Ob} 135 / 04 \mathrm{z}$ and $10 \mathrm{Ob} 80 / 05 \mathrm{w}$; available at www.ris.bka.gv.at.

51 Art. 15 of Reg. 1346/200: '[e]ffects of insolvency proceedings on lawsuits pending -The effects of insolvency proceedings on a lawsuit pending concerning an asset or a right of which the debtor has been divested [Art 4, lex loci concursus] shall be
} 
national law is applied under Article 15. In order to achieve an accord between the decisions, one could argue that the preceding decision should prevail. A preliminary ruling has not been considered by the courts involved in this matter, as the Austrian supreme court considered the question sufficiently clear. So, is the harmony among supreme court decisions about the acquis an independent objective within EU law? Or do we accept that, as with many other instruments of international law, discrepancies are unavoidable in the context of procedural autonomy of the Member States or indeed any other parties to international conventions and other uniform legal instruments?

Conclusion 5: An awareness of legal positions in other jurisdictions is increasingly important for the successful development of an ever closer European Union and free world economy as a whole. In some areas of law some progress can be observed, but a lot of work needs to be put into the foundations of legal theory in order to create a convincing basis for cross-border interaction of the law.

\section{CONCLUSION}

It is important to raise the level of awareness of foreign law and transnational law in legal science and practice, including legislation. The use of transnational law must be improved by suggesting practical methods of application of such law. Prejudices should be replaced by familiarity with concepts of combining different spheres of legal origin and law-making.

governed solely by the law of the Member State in which that lawsuit is pending [lex loci processus].' 